\title{
Medial Supraclavicular Lymph Node
}

National Cancer Institute

\section{Source}

National Cancer Institute. Medial Supraclavicular Lymph Node. NCI Thesaurus. Code C12944.

A cervical lymph node located above the medial region of the clavicle. 